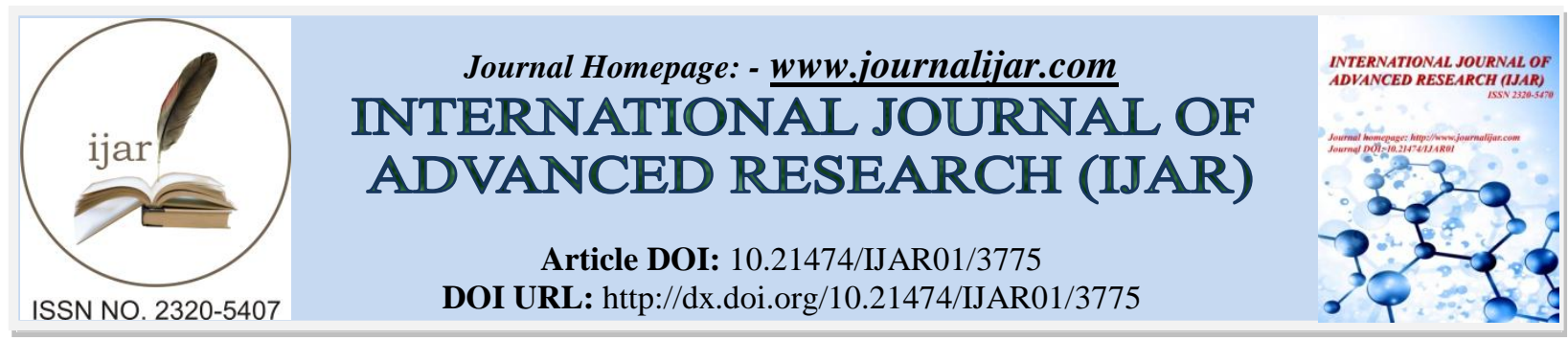

RESEARCH ARTICLE

\title{
COMPARATIVE STUDY ON BACTERIAL LOAD FROM POST-HARVEST VEGETABLES SOLD AT ROAD SIDE AND SUPERMARKET: IN CASE OF JIMMA TOWN, SOUTHWESTERN ETHIOPIA.
}

Demeke Lema, Tokuma Negisho, Meseret Guta and Girma Mosisa.

Department of Biology, College of Natural Sciences, Jimma University, Jimma P.O.Box: 378, Ethiopia.

\section{Manuscript Info}

Manuscript History

Received: 02 February 2017

Final Accepted: 01 March 2017

Published: April 2017

Key words:-

Bacterial load, raw vegetables, unsafe marketing environment, pathogenic bacteria

\begin{abstract}
Vegetables are important protective food and highly beneficial for the maintenance of health and prevention of diseases. However, during growth, harvest, transportation and further handling the product can be contaminated with pathogens from animal and human sources. This study was aimed to assess the bacteriological load of post-harvest vegetables sold at Jimma town markets. A total of 32 vegetable samples were purchased from Ajip and kochi of Jimma town, specifically from road side and supermarket and analyzed for their bacteriological loads following standard bacteriological methods. Result showed that the total aerobic count in cabbage samples( $2.34 \times 10^{9}$ to $\left.2.75 \times 10^{9} \mathrm{cfu} / \mathrm{ml}\right)$ and carrot samples $\left(2.18 \times 10^{9}\right.$ to $2.5 \times 10^{9} \mathrm{cfu} / \mathrm{ml}$ ) taken from the road sides were higher than the total aerobic count for cabbage samples $\left(1.41 \times 10^{9}\right.$ to $\left.1.78 \times 10^{9} \mathrm{cfu} / \mathrm{ml}\right)$ taken from supermarket and carrot samples $\left(1.65 \times 10^{9}\right.$ to $\left.1.72 \times 10^{9} \mathrm{cfu} / \mathrm{ml}\right)$ taken from the shops. The two pathogenic bacteria namely, S. aureus and E.coli were identified from all samples. Samples taken from both shops and road sides were contaminated by pathogenic bacteria. The cabbage and carrot might be contaminated as a result of handling by farmers or retailers. Improper handling and improper hygiene might lead to contamination of raw cabbage and carrot and this might eventually affect the health of the consumers. It is necessary and important that both the farmer who harvests the vegetables into bags for transportation, the marketers and consumers take necessary and appropriate precautions in preventing contamination and eating of contaminated vegetables.
\end{abstract}

Copy Right, IJAR, 2017,. All rights reserved.

\section{Introduction:-}

Vegetables are a complex group of wide varieties of different types of crops. Most vegetables are annual or biennials, completing their life cycle in one or two years respectively. It has diverse form of propagation: by seed or vegetative parts. Many vegetables can be grown under a wide range of conditions, while others have more specific requirements for water, temperature and light (Shanmugavenu, 1989).Vegetables are considered as the leafy outgrowth of plants or plant shoots. These include plants or plant parts used in making soup and served as integral parts of main meal (Yusuf et al., 2004).Vegetables can also be regarded as the edible component of plants, such components includes leaves, stalk, roots, tubers, bulbs, flowers and seed (ICMSF,1998). They are important for food and highly beneficial for the maintenance of health and prevention of diseases. They contain 
valuable food ingredients which are essential for the proper function of the body and also contain various medicinal and therapeutic agents and are valued mainly for their high vitamin and mineral content. Studies have evaluated the association of fruit and vegetables consumption with the reduction of risk of specific diseases (Hung et al., 2004).

Production practices, growth conditions and the location of the edible part during growth can affect their bacterial status, which may affect the health of consumers. Possible sources of these pathogens are soil, faeces (manure, both of human and animal origin), water (irrigation, cleaning), animals (including insects and birds), handling of the products, harvesting and processing equipment, and transportation (Aycicek et al., 2006; Amoah, 2005; Beuchat, 2002).

The occurrence of bacterial populations on vegetables is recognized as a source of potential health hazard to man and animals. This is due to their production of bacteriotoxins compounds which are capable of inducing several critical clinical symptoms in man following ingestion or inhalation; even though they differ in their degree and manner of toxicity. The contamination of vegetables by bacteria could also be as a result of poor handling practices in food supply chain, storage conditions, distribution, marketing practices and transportation (Effiuvwevwere, 2000). Most of raw vegetables are normally consumed without being cooked, so the possibility of food poisoning exists (Aycicek et al., 2006).The increase in consumption has been correlated with an increased frequency of outbreaks of illness associated with fresh vegetables (McMahon and Wilson, 2001).

Numerous outbreaks of illness caused by bacteria have been linked epidemiologically to consumption of fresh vegetables. Increased recognition of fresh vegetables as suspected vehicles of human illness in industrialized countries (Altekruse et al., 1997; Bean and Griffin, 1990) may probably result in increased numbers of associated or confirmed cases in the future. Fresh vegetables recently have a significance source of human pathogens and human contaminants that pose a potential threat to human health worldwide and the contamination is special concern. Because most vegetables likely to be consumed raw without cooking (European Commission, 2002).

Growing and marketing of fresh vegetables in Ethiopia has been complicated by postharvest losses both in terms of quality and quantity between harvest and consumption. In Jimma town, vegetables such as cabbage and carrot are common supplementary diets. The market in the town supply vegetables from the nearby farm lands and far farm lands that cross many hundred kilometers. The problem can be enhanced from poor management of vegetables in the markets. Jimma s town market conditions that favor contamination can be raised from poor hygiene of the vendors, using bacteriologicaly unsafe containers, poor handling practice and unhygienic environmental conditions such as sanitarily unsafe marketing environment. The consequences of the problems are increasing loss of vegetables due to bacterial spoilage and human illness in Jimma town. However, in Jimma town, especially Ajip and Kochi local markets there are no sufficient scientific information on bacterial load of the mentioned vegetables. Therefore, the present study was aimed to assess the bacteriological load of fresh vegetables sold at Jimma town market by considering the aforementioned gap.

\section{Material and Method:-}

\section{Description of the study area:-}

The study was conducted in Jimma town, located $353 \mathrm{~km}$ southwest of Addis Ababa, and the capital city of Ethiopia. The town's geographical coordinates are $7^{\circ} 41^{\prime} \mathrm{N}$ latitude, $36^{\circ} 50^{\prime} \mathrm{E}$ longitude, and an average altitude of 1 , $780 \mathrm{~m}$ above sea level. It lies in the climatic zone locally known as "Woyna Daga" (1,500-2,400 m above sea level) which is considered to be ideal for agriculture as well as human settlement. The town is generally characterized by warm climate with a mean annual maximum temperature of $30^{\circ} \mathrm{C}$ and a mean annual minimum temperature of 14 ${ }^{\circ} \mathrm{C}$ (Alemu et al., 2011).

\section{Study Design and Period:-}

Comparative cross sectional study design was conducted. Samples were collected from the two different local markets (road side and shop), Ajip and Kochi, in Jimma town. The study was conducted from March 2014 to May 2014.

\section{Sampling Techniques:-}

A representative samples were selected by simple random sampling. 
Table 1:- Sampling details of vegetables from Ajip and Kochi local markets.

\begin{tabular}{|c|c|c|c|}
\hline \multirow{2}{*}{ Kochi } & Site & Cabbage & Carrot \\
\cline { 2 - 4 } & k-SH & 4 & 4 \\
\cline { 2 - 4 } & K-ST & 4 & 4 \\
\hline \multirow{2}{*}{ Ajip } & A-SH & 4 & 4 \\
\cline { 2 - 4 } & A-ST & 4 & 4 \\
\hline
\end{tabular}

K-SH: - Samples taken from Kochi local market from the shop, K-ST: - Sample taken from Kochi local market from the street, A-SH: - Samples taken from Ajip local market from the shop, A-ST: - Sample taken from Ajip local market from the street.

\section{Sample Collection:-}

Random sampling procedure was adopted to collect the samples from Ajip and Kochi market. Two commonly used vegetables, namely carrot and cabbage, were selected for the present investigation. The vegetables were purchased and polythene zip bags were used for the collection of samples. Samples were transported aseptically to Microbiology Laboratory Department of Biology, Jimma University for further analysis. The polythene bags with vegetables were kept in the refrigerator at $-14^{\circ} \mathrm{C}$ until it was used.

\section{Sample preparation for microbiological analysis:-}

For sample preparation, $25 \mathrm{~g}$ of the samples were aseptically removed from each sample, shredded into small pieces and vigorously shaken in $225 \mathrm{ml}$ of sterile $0.1 \%(\mathrm{w} / \mathrm{v})$ peptone water for $3 \mathrm{~min}$ separately to homogenize the sample (Shalini,2010). In addition, a serial dilution was made. A $10 \mathrm{~mL}$ of water sample was also mixed with $90 \mathrm{~mL}$ of peptone water using vortex mixer. Finally, appropriate serial dilutions of the suspension were spread-plated on a suitable solid media.

\section{Bacterial Counts}

Colonies on the Petri dishes were counted. Bacterial species were identified by comparing their morphological characters of known taxa and gram staining techniques and then confirmed by the pattern of biochemical reactions using the standard methods (Cheesbrough, 2006). Some of the Gram-negative rods were identified by indole and $\mathrm{H}_{2} \mathrm{~S}$ production, gas formation, citrate utilization, motility and urease test. For Gram-positive bacteria catalase tests was used (Cheesbrough, 2006).

\section{Result:-}

A total of thirty two samples of cabbages and carrots were analyzed in this study. Based on cultural, morphological and biochemical testing, S.aureus, Salmonella spp, Streptococcus spp, pseudomonas sp, E. coli and L.monocytogen were identified (Table 3).

The results obtained from the study associated with the post harvest vegetables showed that total mean aerobic count for cabbage ranged from $1.41 \times 10^{9}$ to $1.78 \times 10^{9} \mathrm{cfu} / \mathrm{ml}$ while total mean coliform count ranged from $1.5 \times 10^{9}$ to $1.66 \times 10^{9} \mathrm{cfu} / \mathrm{ml}$ for the samples taken from the shops. The total mean aerobic count for cabbage ranged from $2.34 \mathrm{x}$ $10^{9}$ to $2.75 \times 10^{9} \mathrm{cfu} / \mathrm{ml}$ while the total mean coliform count ranged from $2.4 \times 10^{9}$ to $2.58 \times 10^{9} \mathrm{cfu} / \mathrm{ml}$ for the samples taken from the road sides. For carrot, the total mean aerobic count ranged from $1.65 \times 10^{9}$ to $1.72 \times 10^{9} \mathrm{cfu} / \mathrm{ml}$ while the total mean coliform count ranged from $1.7 \times 10^{9}$ to $1.92 \times 10^{9}$ for the samples taken from the shops. The total mean aerobic count ranged from $2.5 \times 10^{9}$ to $2.75 \times 10^{9} \mathrm{cfu} / \mathrm{ml}$ while total mean coliform count ranged from $2.47 \mathrm{x}$ $10^{9}$ to $2.58 \times 10^{9}$ those samples taken from the road sides. 
Table 2:- Bacterial mean colony count $(\mathrm{cfu} / \mathrm{ml})$ for each post harvest vegetable.

\begin{tabular}{|l|l|c|c|}
\hline Sample & Location & Total Aerobic Counts $(\mathrm{cfu} / \mathrm{ml})$ & Total Coliform Counts (cfu/ml) \\
\hline \multirow{4}{*}{ Cabbage } & K-SH & $1.78 \times 10^{9}$ & $1.5 \times 10^{9}$ \\
\cline { 2 - 4 } & K-RS & $2.34 \times 10^{9}$ & $2.4 \times 10^{9}$ \\
\cline { 2 - 4 } & A-SH & $1.41 \times 10^{9}$ & $1.66 \times 10^{9}$ \\
\cline { 2 - 4 } & A-RS & $2.75 \times 10^{9}$ & $2.58 \times 10^{9}$ \\
\hline \multirow{5}{*}{ Carrot } & K-SH & $1.65 \times 10^{9}$ & $1.92 \times 10^{9}$ \\
\cline { 2 - 4 } & K-RS & $2.5 \times 10^{9}$ & $2.47 \times 10^{9}$ \\
\cline { 2 - 4 } & A-SH & $1.72 \times 10^{9}$ & $1.7 \times 10^{9}$ \\
\cline { 2 - 4 } & A-RS & $2.18 \times 10^{9}$ & $2.42 \times 10^{9}$ \\
\hline
\end{tabular}

Based on morphology and biochemical tests six bacteria were isolated from cabbage and carrot samples. Morphologically, two spherical shape bacteria namely S.aureus and Streptococcus spp. and four rod shaped bacteria such as Pseudomonas spp., E.coli, Salmonella spp. and L.monocytogen were identified. Based on gram reaction, three gram positive bacteria such as S.aureus, Streptococcus spp. and L.monocytogen and three gram negative bacteria were isolated. This result showed that all bacterial isolates were catalase positive except Streptococcus spp.

Table 3:- Bacterial isolates based on morphology and biochemical test from Kochi and Ajip local markets.

\begin{tabular}{|c|c|c|c|}
\hline \multirow[t]{2}{*}{ Identified bacteria } & \multirow{2}{*}{$\begin{array}{l}\text { Morphological } \\
\text { characters }\end{array}$} & \multicolumn{2}{|c|}{ Biochemical test } \\
\hline & & Gram reaction & Catalase test \\
\hline S. aureus & spherical & + & + \\
\hline Streptococcus spp. & spherical & + & - \\
\hline Pseudomonas spp. & bacilli (rod) & - & + \\
\hline E. coli & bacilli( rod) & - & + \\
\hline Salmonella spp. & bacilli( rod) & - & moderate $(+)$ \\
\hline L. monocytogen & bacilli (rod) & + & + \\
\hline
\end{tabular}

(-) Gram negative and catalase positive (+), Gram positive and catalase negative

This result (table.4) showed that S. aureus and E. coli were isolated from Ajip and Kochi local markets shops and road sides. The prevalence of $S$. aureus in cabbage and carrot samples in the two markets have shown the degree at which such a $S$. aureus proliferate and compete successfully in respect of the other bacteria. Salmonella was observed only in Ajip and Kochi shops. Pseudomonas was only observed in cabbage samples.

Table 4:- Prevalence of six bacteria isolated from vegetables sampled in Ajip and Kochi local market, Jimma town.

\begin{tabular}{|c|c|c|c|c|c|c|c|c|}
\hline \multirow{3}{*}{ Bacteria isolates } & \multicolumn{8}{|c|}{ Vegetable Samples } \\
\hline & \multicolumn{4}{|c|}{ Cabbage } & \multicolumn{4}{|c|}{ Carrot } \\
\hline & $\mathrm{K}-\mathrm{SH}$ & K-ST & A-SH & $\mathrm{A}-\mathrm{ST}$ & $\mathrm{K}-\mathrm{SH}$ & $\mathrm{K}-\mathrm{ST}$ & A-SH & A-ST \\
\hline S.aureus & + & + & + & + & + & + & + & + \\
\hline Streptococcus sp. & + & - & + & - & $=$ & + & - & + \\
\hline Pseudomonas sp. & _ & + & - & + & _ & _ & _ & - \\
\hline E.coli & + & - & + & + & + & + & + & + \\
\hline Salmonella sp. & + & $\ldots$ & $\ldots$ & - & - & - & + & - \\
\hline L.monocytogen & _ & + & _ & + & - & _ & - & - \\
\hline
\end{tabular}

(-) indicate that no isolate,

$(+)$ indicate the presence of bacteria

This result (figure.1) showed that (35.7\%) of bacteria were isolated from samples taken from Ajip local market road sides followed by $(28.6 \%)$ of bacteria were isolated from Kochi local market road sides. However; the frequency of occurrence of bacterial isolates from Kochi shops was $(21.4 \%)$ as compared to the frequency of bacteria isolated from Ajip shops (14.3\%). 
Fig 1:- Percentage of occurrence of bacteria associated with contaminated Cabbage in Kochi and Ajip local market, Jimma town.

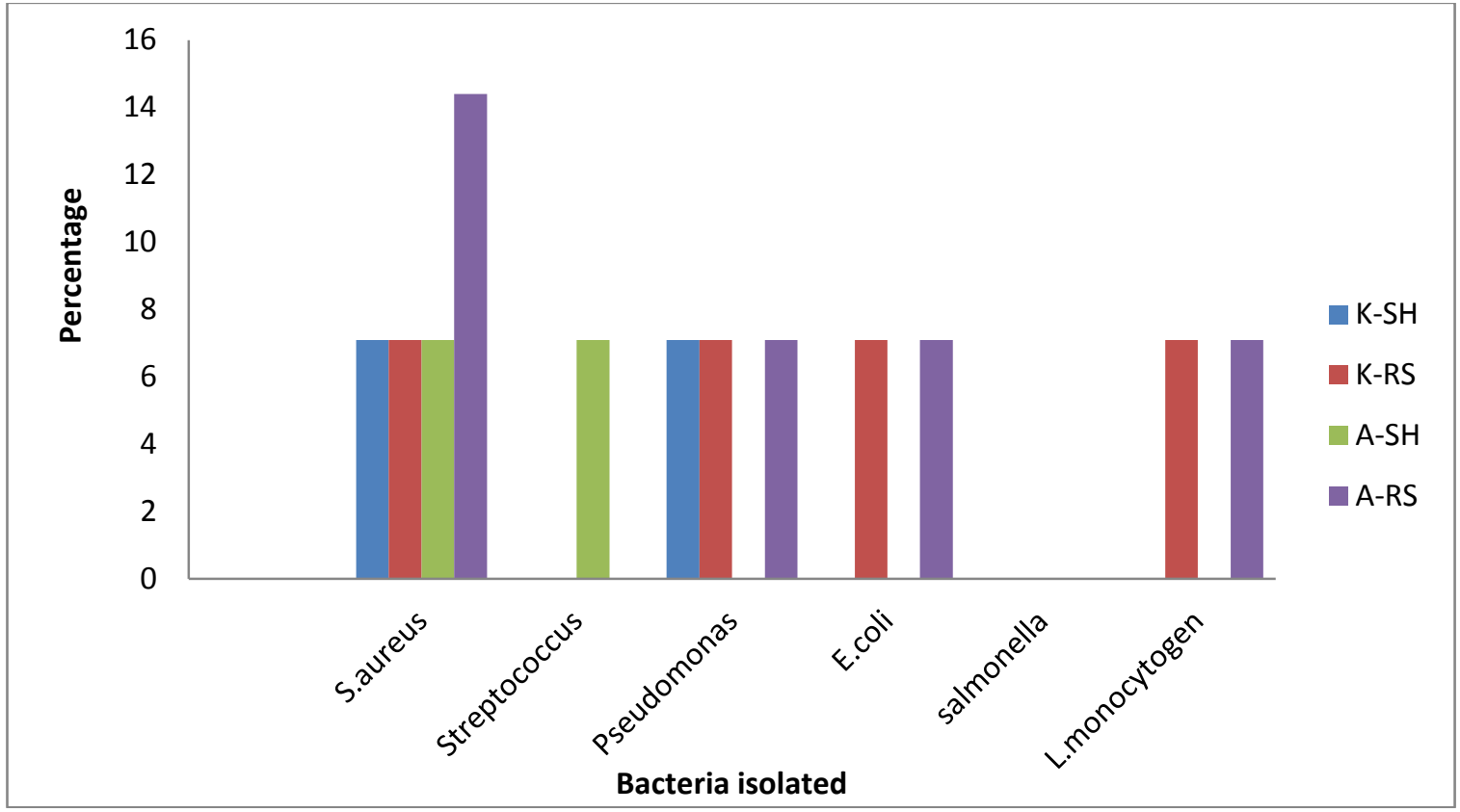

The percentage of occurrences of bacteria associated with contaminated carrot samples taken from Kochi and Ajip shops and road sides. This result showed that (36.4\%) of bacteria were isolated from samples taken from Ajip local market road sides. Similarly, (36.4\%) of bacteria were isolated from Kochi local market road sides. However; the frequencies of occurrence of bacterial isolates from Ajip shops was (18.2\%) as compared to the frequency of bacteria isolated from Kochi shops (9.1\%).

Fig. 2:- Percentage of occurrences of bacteria associated with contaminated carrot in Kochi and Ajip, Jimma town.

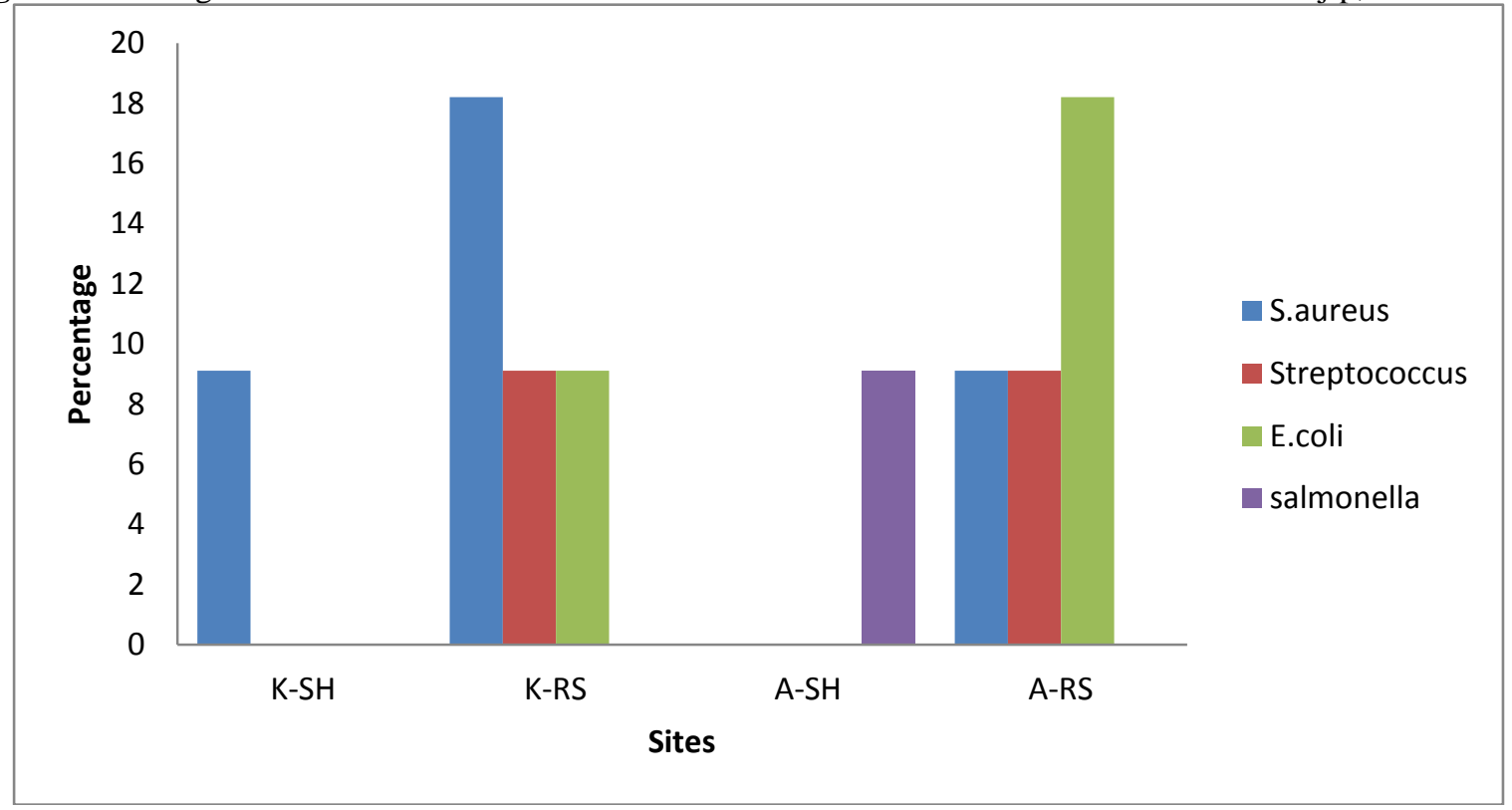

The frequency of occurrence of bacterial isolates from the road sides $18(72 \%)$ were higher than that of the shops $7(28 \%)$ table.5. In the shops, the samples were kept on the shelves which prevent vegetables from fecal contamination from the soil. S. aureus 6(24\%) were most predominant bacterial isolates associated with contaminated vegetables samples from road sides and 4(16\%) samples taken from the shops. This was followed by 
E. coli $5(20 \%)$ were detected in vegetable samples taken from road sides and 1(4\%) from the shops. However, Pseudomonas spp., Streptococcus spp. and L.monocytogen were not detected in the samples taken from the shops.

Table 5:- Frequency of occurrences of bacteria associated with contaminated vegetables in shops and road side, Jimma town.

\begin{tabular}{|c|c|c|c|c|c|}
\hline \multirow[t]{2}{*}{ Identified bacteria } & \multirow{2}{*}{$\begin{array}{c}\text { Frequency } \\
(\%)\end{array}$} & \multicolumn{2}{|c|}{ vegetable samples } & \multicolumn{2}{|c|}{ Site } \\
\hline & & Cabbage (\%) & Carrot $(\%)$ & Shop (\%) & Road side $(\%)$ \\
\hline S.aureus & $10(40)$ & $5(20)$ & $5(20)$ & $4(16)$ & $6(24)$ \\
\hline Streptococcus sp. & $3(12)$ & $1(4)$ & $2(8)$ & - & $3(12)$ \\
\hline Pseudomonas sp. & $2(8)$ & $2(8)$ & - & - & $2(8)$ \\
\hline E.coli & $6(24)$ & $3(12)$ & $3(12)$ & $1(4)$ & $5(20)$ \\
\hline Salmonella sp. & $2(8)$ & $1(4)$ & $1(4)$ & $2(8)$ & - \\
\hline L.monocytogen & $2(8)$ & $2(8)$ & - & - & $2(8)$ \\
\hline Total & $25(100)$ & $14(56)$ & $11(44)$ & $7(28)$ & $18(72)$ \\
\hline
\end{tabular}

The percentage of occurrences of bacteria associated with contaminated vegetables from Ajip and road Kochi was shown in (Fig. 3).This result showed that the percentage of bacteria isolated in vegetable samples taken from Kochi local market (52\%) was higher than the percentage of bacteria isolated from Ajip local market $(48 \%)$.

Fig. 3:- Percentage of occurrences of bacteria associated with post harvest vegetables from Ajip and Kochi, Jimma

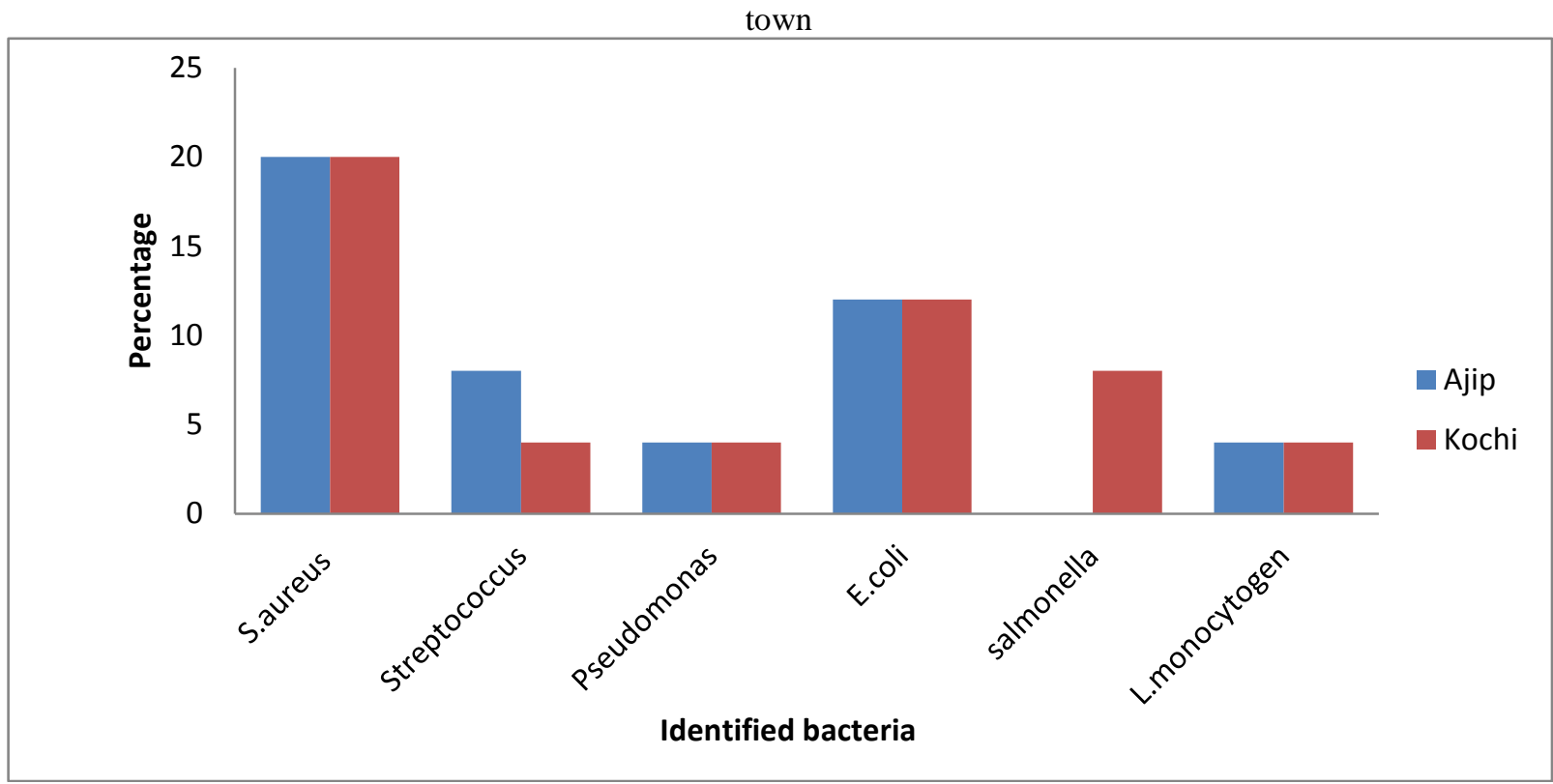

\section{Discussion:-}

In this study the total mean aerobic count for cabbage ranged from $1.41 \times 10^{9}$ to $1.78 \times 10^{9} \mathrm{cfu} / \mathrm{ml}$ while total mean coliform count ranged from $1.5 \times 10^{9}$ to $1.66 \times 10^{9} \mathrm{cfu} / \mathrm{ml}$ for the samples taken from the shops. The total mean aerobic count for cabbage ranged from $2.34 \times 10^{9}$ to $2.75 \times 10^{9} \mathrm{cfu} / \mathrm{ml}$ while the total mean colifom count ranged from $2.4 \times 10^{9}$ to $2.58 \times 10^{9} \mathrm{cfu} / \mathrm{ml}$, for samples taken from the road side. For carrot, the total mean aerobic count ranged from $1.65 \times 10^{9}$ to $1.72 \times 10^{9} \mathrm{cfu} / \mathrm{ml}$ while the total mean coliform count ranged from $1.7 \times 10^{9}$ to $1.92 \times 10^{9} \mathrm{cfu} / \mathrm{ml}$ those samples taken from the shops. The total mean aerobic count ranged from $2.5 \times 10^{9}$ to $2.75 \times 10^{9} \mathrm{cfu} / \mathrm{ml}$ while total mean coliform count ranged from $2.47 \times 10^{9}$ to $2.58 \times 10^{9} \mathrm{cfu} / \mathrm{ml}$ those samples taken from the road sides. However, the result reported by (Adebayo et al., 2012), the pathogenic bacteria associated contaminated vegetables showed that the total aerobic count for cabbage ranged from $1.43 \times 10^{6}$ to $2.10 \times 10^{6} \mathrm{cfu} / \mathrm{ml}$ while the total coliform count ranged from $3.10 \times 10^{6}$ to $4.2 \times 10^{6} \mathrm{cfu} / \mathrm{ml}$. The total aerobic count for carrot ranged from $2.07 \times 10^{6}$ to $2.20 \times 10^{6} \mathrm{cfu} / \mathrm{ml}$ while total coliform count ranged from $2.8 \times 10^{6}$ to $3.0 \times 10^{6} \mathrm{cfu} / \mathrm{ml}$. In comparison, the present results showed that there were high microbial load than the result presented by the above microbiologists. This was probably due to the climatic condition and altitude of the two vegetables market towns (Jimma, Ethiopia and Uyo metropolis, Nigeria), 
the difference in the people, the hygienic status of the marketing sites and storage rooms, the hygienic status of the retailers, the duration of storage periods and the place and distance in which vegetables were came.

In the current study $S$. aureus was highly prevalent in both cabbage and carrot samples in the two markets followed by E.coli and salmonella spp. was the least abundant bacteria were observed. The prevalence of $S$. aureus in almost all the vegetables in the two markets have shown the degree at which such a microbe proliferate and compete successfully in respect of the other bacteria. This finding was in conformity with that of Uzeh et al (2009), who reported that, the presence of $S$. aureus in carrots, cucumber, cabbage and lettuce at food outlets within Lagos Metropolis, Northern Nigeria. And also it is in agreement with the work of Erin (2010), who reported that Pseudomonas spp., Staphylococcus spp. and Streptococcus spp. were the major bacterial species that were generally present on all vegetables in Kaduna markets, Northern Nigeria.

The presence of $S$. aureus, pathogenic bacteria has public health concern and significance. The cabbage and carrot might be contaminated as a result of handling by farmers or retailers. Improper handling and improper hygiene might lead to contamination of raw cabbage and carrot and this might eventually affect the health of the consumers. Most of bacteria isolated in this study are those commonly found in soil and water. The presence of the most frequently isolated index of food quality and indicators of fecal contamination such as E.coli and salmonella sp. reported in this study are an indication of fecal contamination of fresh cabbage and carrot as a result of unhygienic handling (Omemu and Bakole, 2005).

This study showed that (36.4\%) of bacteria were isolated from samples taken from Ajip local market road sides. Similarly, (36.4\%) of bacteria were isolated from Kochi local market road sides. However; the frequencies of occurrence of bacterial isolates from Ajip shops was (18.2\%) as compared to the frequency of bacteria isolated from Kochi shops (9.1\%). This difference may due to the hygiene of marketing area, sanitation of the retailers, the storage rooms and the duration of storage periods.

The results showed that S. aureus 6(24\%), E. coli 5(20\%), Streptococcus spp.,3(12\%), pseudomonas sp. and L.monocytogen $4(16 \%)$ totally $18(72 \%)$ were found in the road side. However, salmonella was not detected from road sides. On the other hand, half of identified pathogenic bacteria such as S. aureus 4(16\%), Escherichia coli $1(4 \%)$, and salmonella $2(8 \%)$, totally $7(28 \%)$ were detected from the samples taken from the shops. This result was in agreement with Viswanathan (2001), reported that the presence of salmonella, S.aureus, fecal E.coli and pseudomonas spp. in cabbage and carrot.

\section{Conclussion:-}

This study showed that vegetables produced in Jimma town represent a bacteriologically unsafe for consumers. It is necessary and important that both the farmer who harvests the vegetables into bags for transportation, marketers and consumers take necessary and appropriate precautions in preventing the risk. From this study, some of isolated bacteria have serious public health risk while others fasten spoilage of the vegetables. High numbers of these pathogenic bacteria in post harvest vegetables would lead to the consumer's illness with attendant symptoms and consequences of the particular or combined microbial presence. Reduction of risk for human illness associated with fresh vegetables can be better achieved through controlling points of potential contamination in the field during harvesting, during processing, storage or distribution in the retail markets food services facilities or at home. Generally, post harvest vegetables of road side are harboring many bacterial contaminants and pathogens as compared to of shops, indicating that these are protected from contamination while subsequent handling, packaging, and storage. Thus, one should buy fresh vegetables from Shop, as they are bacteriologically safe. It is therefore urgent to sensitize the consumers and retailers about vegetable contamination problems. Further studies could be recommended to evaluate the bacterial pathogens at strain level and their antimicrobial resistance pattern.

\section{Acknowledgement:-}

The authors would like to extend special thank to Jimma University, College of Natural Sciences particularly Department of Biology for giving materials and laboratory space. 


\section{References:-}

1. Adebayo-Tayo BC, Odu NN, Esen CU, Okonko IO. (2012). Microorganisms Associated With Spoilage Of Stored Vegetables In Uyo Metropolis, AkwaIbom State, Nigeria. Nature and Science 10(3):23-32.

2. Alemu A, Tsegaye W, Golosa L and Abebe G. (2011).Urban malaria and associated risk factors in Jimma town, South West Ethiopia. Malar J. 10:173-200.

3. Altekruse SF, Cohen ML, Swerdlow DL. (1997). Emerging food borne diseases. Emerg. Infect. Dis., 3:285-293.

4. Amoah P. (2005).Irrigated urban vegetable production in Ghana: sources of pathogen contamination and risk elimination.

5. Aycicek H., Oguz U. and Karci K. (2006).Determination of total aerobic and indicator bacteria on some raw eaten vegetables from wholesalers in Ankara, Turkey. International Journal of Hygiene and Environmental Health 209: 197-201.

6. Bean NH, Griffin PM. (1990). Forborne disease outbreaks in the United States, 1973 -1987: pathogens, vehicles and trends. J. Food Prot., 53:807-814.

7. Beuchat LR. (2002). Ecological factors influencing survival and growth of human pathogens on raw fruits and vegetables. Microbes and Infection 4: 413-423.

8. Cheesbrough, M.(2006). District Laboratory Practice in Tropical Counties. Part 2. 2nd Edition. Cambridge University Press. The Edinburgh Building, Cambridge CB28RU, UK. pp 45-70.

9. Effiuvwevwer BO .(2000). Microbial spoilage agents of Tropical and assorted fruits and Vegetables (An Illustrated References Book).Paragraphics Publishing Company, Port Harcourt, 1-39.

10. Erin S (.2010). Influence of pre-harvest factor on post- harvest quality. Biochemistry, 2:133-145.

11. European Commission .(2002). Risk profile on the microbiological contamination of fruits and vegetables eaten raw. From: http://europa.eu.int/comm/food/fs/sc/scf/index -en.html accessed on 12/11/2011.

12. Hung HC, Joshipura KJ, Jiang R, Hu FB, Hunter D, Smith-Warner SA, Colditz GA, Rosner B, Spiegelman D, Willett WC.2004. Fruit and vegetable intake and risk of major chronic disease. 96(21):1577-84.

13. ICMSF (International Commission on Microbiological Specification for Foods) .(1998).Microorganisms in foods, Microbial Ecology of food commodities. New York, Blackie Academics and Professional 6: 617.

14. McMahon MA and Wilson IG .(2001).The occurrence of enteric pathogens and Aeromonas species in organic vegetables. International Journal of Food Microbiology 70:155-162.

15. Omemu AM, Bankole MO. (2005). Ready-to-eat (RTE) vegetable salad: effect of washing and storage temperature on the microbial quality and shelf-life. In: the Book of Abstract of the 29th Annual Conference \& General Meeting (Abeokuta 2005) on Microbes As Agents of Sustainable Development, organized by Nigerian Society for Microbiology (NSM), UNAAB, from 6-10th Nov, 28.

16. Shalini S. (2010). Study on microbiological aspects of Fresh fruits and vegetables (including green leafy vegetables) in and around national capital region (NCR). Bhaskaracharya College of applied sciences

17. Shanmugavelu KG (1989). Production Technology of Vegetable Crops.Oxford \& IBH Publications, Delhi.9-18.

18. Uzeh RE, Alade FA and Bankole M. (2009). The microbial quality of pre-packed mixed vegetable salad in some retail outlets in Lagos Nigeria. African Journal of Food Science, 3: 270-272.

19. Viswanathan P.(2001). Prevalence and growth of pathogens on salad vegetables and sprouts. International Journal of Hygiene \& environmental health, 203(3): 205- 213 .

20. Yusuf IZ, Oyaweye OM. Yongab KA, Pemu AT (2004). Bacteriological Quality Assessment of Salad Vegetables sold in Bauchi Metropolis. Nigeria Journal of Microbiology 18:316-320. 